\title{
Does Speculation Matters for Wheat Price Shocks?
}

\author{
Gökhan Çinar ${ }^{1}$, Adnan Hushmat ${ }^{2}$, Ayşe Uzmay ${ }^{3}$ \\ ${ }^{1}$ Department of Agricultural Economics, Adnan Menderes University, Aydın, Turkey \\ ${ }^{2}$ Department of Business Administration, Antalya International University, Antalya, Turkey \\ ${ }^{3}$ Department of Agricultural Economics, Ege University, Antalya, Turkey \\ Email: gokhan.cinar@adu.edu.tr, adnan.hushmat@gmail.com, ayse.uzmay@ege.edu.tr
}

Received 12 July 2015; accepted 11 August 2015; published 14 August 2015

Copyright (C) 2015 by authors and Scientific Research Publishing Inc.

This work is licensed under the Creative Commons Attribution International License (CC BY). http://creativecommons.org/licenses/by/4.0/

\section{(c) (i) Open Access}

\begin{abstract}
The purpose of this research is to study the relation between wheat price shocks and speculative movements. VAR model is developed to analyze the data. Impulse-Response functions and Variance Decomposition method are used to analyze the size of relationship among the variables. Wheat prices are effected significantly by speculative movements in the short-run. The relation loses its significance after three months. The effect of speculation on wheat prices can lead to negative reaction from the producers; that will be harmful for an economy as a whole. In order to prevent this, effective use of the government policies is needed; so that, in the long-run, not only economic but also speculative based price structure can be achieved. The disclosures of global wheat yield estimated by the authorities can be a helpful tool in order to control speculative movements and in achieving long-run market equilibrium. This study encompasses a bigger picture and provides an opportunity to have a deeper and broader look into the dynamics of wheat prices. Thus, it can be advantageous for traders as well as for policy makers.
\end{abstract}

\section{Keywords}

Wheat, Price Shocks, VAR Model, Speculation

\section{Introduction}

The dynamics of commodity prices is among the important risk factors effecting inflation in an economy. Explaining these dynamics is important for an economy. Price volatilities evolving in these dynamics, under certain limits, are important for a smooth working of an economy. However, if these volatilities go beyond certain limits, not only the consumers and producers but also the whole economy is effected. High volatility in the economy increases uncertainty in the prices and leads to market manipulation. An example of high volatility in the 
prices of food products was seen during 2005-08. This high volatility posed a serious threat to the global economy. Especially the abnormal rise in food prices caused famine, starvation and many political agitations against the governments. Cereal exports of the big cereal producers like Argentina, China, India, Russia and Ukraine reduced. As a result, the pressure on cereal prices increased (see Figure 1$)^{1}$.

This study analyzes the developments in cereal prices by focusing on one of the cereal products, the wheat. This is one of the most important products in food and trading for almost every country; and also it's an important product in commodity markets.

Wheat prices showed 46\% increase during 2005-08, 10\% decrease during 2009-10, 35\% increase in 2011 and again a $17 \%$ increase in July, 2012. As a whole, there is an increase of $126 \%$ in wheat prices during the last ten years.

Let's have a brief periodic analysis of world wheat production. Its production has increased to $8.7 \%$ in the last 12 years. However there was a negative trend in the production in 2005-08. In contrast, due to increase in the demand, the wheat trade climbed to 139 million ton with an increase of 13 million ton during the same period. Table 1 shows the changings in the world wheat production, trade, consumption and stock level during 2000-12.

The international trade volume of wheat was $\$ 14$ billion in 2000, whereas, in 2008, it was $\$ 44$ billion. Wheat has become the most traded agriproduct in the world. One of the most important factors, for this extraordinary increase in wheat trade volume, is the increase in its price. In 2000, its price was $\$ 120 /$ ton, whereas, in 2008 , it was $\$ 342 /$ ton, an increase of almost 3 times (see Figure 2).

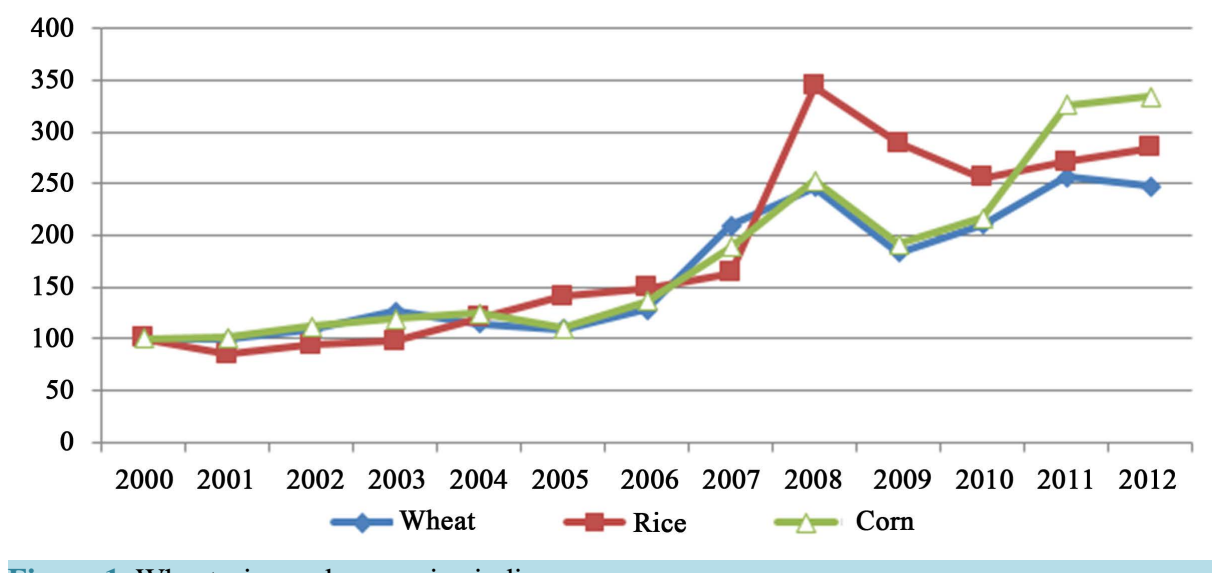

Figure 1. Wheat, rice and corn price indices.

Table 1. World wheat production, trading, consumption and stock levels changings during 2000-2012 (million ton).

\begin{tabular}{|c|c|c|c|c|c|c|c|}
\hline Year & Production & Supply & Consumption & Trade & Closing stocks & World usage (\%) & $\begin{array}{c}\text { Stock levels } \\
\text { of big exporters (\%) }\end{array}$ \\
\hline $2002 / 03$ & 574.0 & 812.9 & 611.3 & 103.0 & 206.2 & 34.3 & 19.8 \\
\hline 2003/04 & 561.5 & 767.7 & 601.1 & 103.8 & 163.8 & 26.5 & 17.7 \\
\hline $2004 / 05$ & 632.7 & 794.4 & 617.9 & 112.4 & 177.9 & 28.4 & 20.9 \\
\hline $2005 / 06$ & 625.6 & 803.5 & 624.2 & 111.2 & 174.2 & 27.6 & 21.3 \\
\hline $2006 / 07$ & 601.0 & 775.2 & 627.9 & 113.7 & 150.2 & 23.9 & 14.1 \\
\hline 2007/08 & 611.2 & 761.5 & 629.1 & 113.5 & 130.7 & 20.2 & 12.9 \\
\hline 2008/09 & 683.9 & 814.6 & 645.7 & 140.9 & 159.9 & 24.4 & 18.1 \\
\hline 2009/10 & 685.7 & 845.6 & 656.1 & 130.6 & 188.8 & 28.7 & 21.7 \\
\hline 2010/11 & 655.4 & 844.3 & 658.7 & 125.9 & 185.4 & 26.6 & 20.8 \\
\hline 2011/12 & 701.5 & 886.9 & 696.7 & 146.8 & 183.2 & 26.7 & 18.4 \\
\hline 2012/13 & 659.6 & 842.8 & 685.4 & 139.0 & 164.1 & 23.7 & 14.7 \\
\hline
\end{tabular}

\footnotetext{
${ }^{1}$ All tables and figures are given at the end of the manuscript.
} 


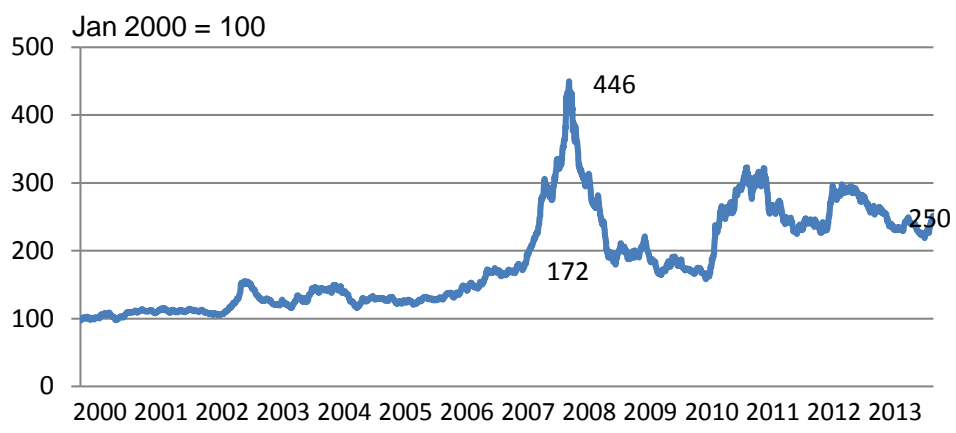

Figure 2. The uncertainty in world wheat prices. Source: IGC Price Statistics, Yearly, 2000-2013, $2000=100$.

In Cannes Summit, G-20 members, the leading actors in agriculture markets and own $65 \%$ of the world cultivable land, kept these extraordinary developments in wheat prices on their agenda. In this meeting, it was decided to control the position limits in agriculture derivatives markets, increasing transparency and tighter regulations in commodity markets [1]. According to the estimates made by IGC (International Grains Council), in the upcoming periods, the wheat production will decrease and stock levels will also reduce. All the above arguments support the importance of non-market based factors for wheat prices.

This study encompasses a bigger picture and provides an opportunity to have a deeper and broader look into the dynamics of wheat prices. This was a brief introduction to this study. In the following section, a comprehensive review of the previous studies is given. Later on, data and model are presented. Then, a brief discussion on research findings is given. Lastly, conclusion of the study is presented.

\section{Previous Studies}

The empirical studies that studied the shocks in food prices can be grouped under the following five heads based on the factors they focused on: a) the studies focusing on the factors causing changes in stock (e.g. increase in the demand of non-food items due to bio-gas programs of USA and EU), increase in food demand because of high growth in some developing countries like China [2]-[6]; b) the ones which focused on the factors effecting the supply (e.g. environmental conditions) [7] [8]; c) the ones focusing on the factors effecting the use of inputs (e.g. changes in energy prices) [7] [9] [10]; d) the ones focusing on the factors effecting monetary policies (e.g. macro variables of developed countries) [11]; e) the ones focusing on speculative behaviors [12]-[16].

According to economics theory, the effect of stock level on price volatility is a known fact. In empirical studies, the effect of speculation and macro variables on the price volatility has been studied a lot. After the last food crisis of 2005-08, Wright [17] tried to put light on the relation of price volatility and stock usage. The main focus of the study was bio-gas programs. Due to these programs and environmental conditions stock supply had been reduced and as a result price volatility had increased. Ott [18] investigated the effect of macro variables, derivative markets and stock level on selected agriculture products and his results supported Wright's [17] study. Serra et al. [19] studied the effect of low stock levels on the price volatility of corn products and put light on the importance of government policies. In general, the results of various studies showed, low stock levels tend to increase the food price volatility [6] [20]-[22]. But there are some other researchers having some different ideas. Roache [11] investigated the effect of petrol prices, speculation, stock level, macro-economic indicators and weather conditions on the volatility in wheat market. The results showed significant effect of macro variables on food prices and insignificant effect of stock conditions. Balcombe [23] studied the relation between the price volatility of different agriproducts and petrol prices, stock and exchange rate volatility. The results of the study showed, the stock and macro factors effect the price volatility of different agroproducts in different time periods. Furthermore, Gilbert [13] also found the higher effect of macro factors instead of micro factors in increasing the volatility of food prices. He also negated the effect of the reduction in stock supply due to bio-gas programs on food price volatility. Many other researchers also found the significant effect of macro factors on food price volatility [3] [9] [24] [25]. Moreover, the researchers like Calvo [26] are of the view; macro variables effect micro functioning. According to this view, loose monetary policy creates a new investment group in future markets and increases the instability of spot markets. The findings of Sanders and Sanders et al. [27] and Irwin et al. [14] 
put the viability of the above claim in controversy. McPhail, et al. [28] found significant short term effect of speculation on price instability in corn market but in long term the effect of speculation is vanished. Ott [18] showed, yearly data obtained from future market has a stabilizing effect in the market.

If we evaluate the literature as a whole, we will come to know that there are two contrary views among the researchers. One group thinks that the market-based factors effect food price volatility, while the other one is in favor of speculative effects. This study focuses on effect of speculative movements on wheat prices.

\section{Data and Model}

This study analyzes the interaction among the change in wheat hedge positions and wheat spot market prices. Figure 3 shows the time series of the variables used in this study. Logarithmic values of the series are used. The series are adjusted for seasonality; and using suitable unit root tests, stationary series are obtained. Quarterly data from 1998:01 to 2012:12 is used. The data about wheat hedge positions is taken from the databank of U.S. Commodity Futures Trading Commission [29]. Wheat spot market prices are taken from the official website of Agriculture Ministry, USA (USDA, 2013) [30].

The method used in this study to calculate the change in hedge positions is as follows:

$$
\begin{gathered}
T=1+\frac{S S}{H S+H L} \text { if } H S>H L \\
T=1+\frac{S S}{H S+H L} \text { if } H S>H L \\
T=1 \text { if } H S>H L=0
\end{gathered}
$$

where; $S S(S L)$ shows speculative or non-commercial short (long) positions and $H S(H L)$ shows hedge/comercial positions of short (long) positions. The equilibrium for this market should be:

$$
S S+S L=S L+H L
$$

After making seasonal adjustments, unit root tests are conducted to check the stationarity of the series. Based on ADF (Augmented Dickey-Fuller) unit root test, the stationary series are obtained at (Table 2). As the series are stationary at different degrees, it is unfeasible to do cointegration test [31]. Hence, standard VAR model is used to conduct the study.

\section{Research Findings and Discussion}

VAR model is used to detect causality between non-stationary and non-cointegrated variables, whereas, VECM (Vector Error Correction Model) is used to find causality between non-stationary but cointegrated variables [32].

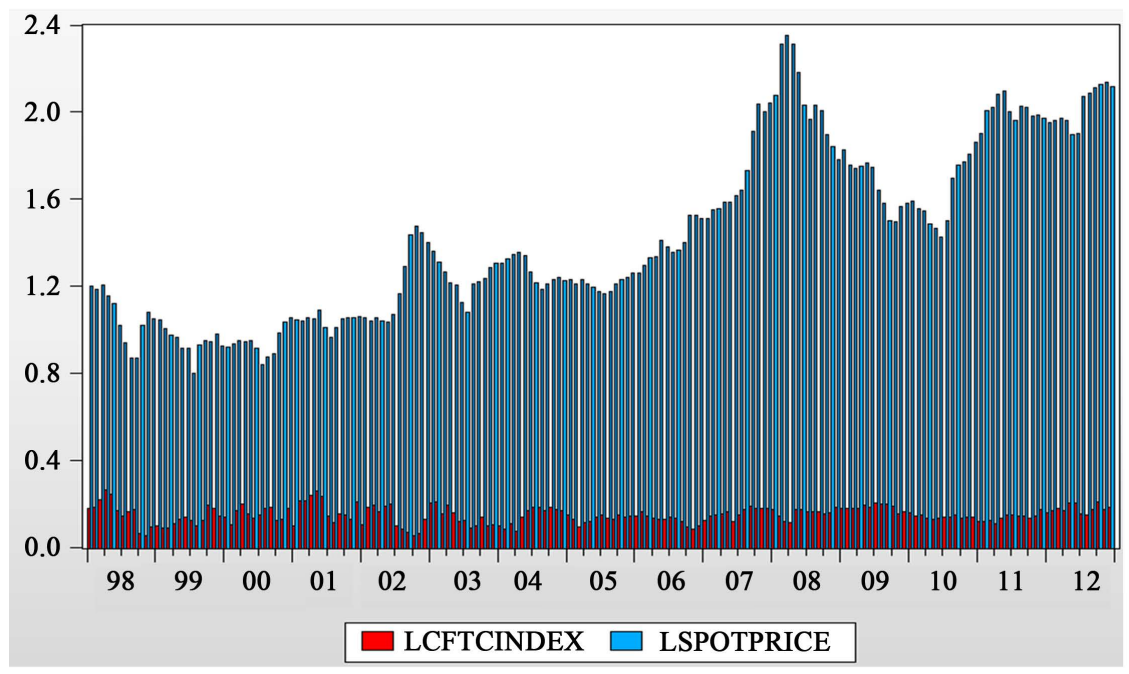

Figure 3. Time series of the variables. 
Table 2. Augmented dickey-fuller unit root test result.

\begin{tabular}{|c|c|c|c|c|c|}
\hline \multicolumn{2}{|c|}{ Wheat spot price } & t-Statistic & Prob. $^{*}$ Speculation index & t-Statistic & Prob. $^{*}$ \\
\hline \multicolumn{2}{|c|}{ Augmented Dickey-Fuller test statistic } & -3.424410 & 0.0514 & -5.922587 & 0.0000 \\
\hline \multirow[t]{3}{*}{ Test critical values: } & $1 \%$ level & -4.010440 & & -4.010143 & \\
\hline & $5 \%$ level & -3.435269 & & -3.435125 & \\
\hline & $10 \%$ level & -3.141649 & & -3.141565 & \\
\hline \multicolumn{2}{|c|}{ Augmented Dickey-Fuller test statistic } & -8.983362 & 0.0000 & - & \\
\hline \multirow[t]{3}{*}{ Test critical values: } & $1 \%$ level & -4.010440 & & - & \\
\hline & $5 \%$ level & -3.435269 & & - & \\
\hline & $10 \%$ level & -3.141649 & & & \\
\hline
\end{tabular}

As the variables used in this study are non-stationary and non-cointegrated, VAR model is used to analyze the relationship between them. VAR model can be represented as following [33]:

$$
y_{t}=\sum_{i=0}^{k} A_{i} \Gamma_{t-i}+C u_{t}, \quad t=1,2, \cdots, T
$$

In the Equation (1), $T$ represents number of observations; $\left(A_{i}\right)$ shows matrix of size $(d \times d)$ containing coefficients of variable $d$ at time $t$; $\left(u_{t}\right)$ shows residuals vector of size $(d \times 1)$; $(C)$ shows a matrix of size $(d \times d)$ containing error coefficients of vector $(\Gamma)$ and $(k)$ shows lag structure. In the first step of VAR model, suitable lag structure is determined. It is clear in Table 3; FPE (Final Prediction Error), AIC (Akaike), SC (Schwarz) and HQ (Hannan Quinn) information criteria identify first lag. Hence first lag is used.

Using this lag structure, the stability of VAR model is tested using the following tests. The consistency of VAR model with this lag structure is tested using following tests.Sequential dependency of this VAR model is checked using LM test. The probability values of LM test show that the VAR model used in this study is consistent (see Table 4).

In Figure 4, unit circle analysis of inverse root of AR characteristic polynomial is shown. It is clear that no modulus value is outside the reference interval. None of the AR roots are outside the unit circle. This result shows that our VAR model is stationary.

Infinite lagged Vector Moving Average (VMA) can be obtained from stationary VAR model as follows:

$$
y_{t+s}-E_{t}\left(y_{t+s}\right)=\sum_{i=0}^{s-1} \psi_{i} u_{t+s-i}
$$

Here, impulse response functions can be found as follows:

If $\Gamma(L)^{-1} \Psi(L)=I$, then

$$
\left(I-\Gamma_{1} L-\Gamma_{2} L^{2}-\cdots-\Gamma_{p} L^{p}\right)\left(I+\Psi_{1} L+\Psi_{2} L^{2}+\Psi_{3} L^{3}+\cdots\right)=I
$$

and if coefficient of $L$ is made zero on the basis of stationarity condition $\Psi_{2}=\Gamma_{1} \Psi_{1}+\Gamma_{2}$ at this point coefficient matrix of impulse response function for $s$ period can be calculated as

$$
\Psi_{s}=\Gamma_{1} \Psi_{s-1}+\Gamma_{2} \Psi_{s-2}+\cdots+\Gamma_{p} \Psi_{s-p}, \quad s=1,2, \cdots\left(\Psi_{0}=I_{k} \& \Psi_{s}=0, s>p\right)
$$

Impulse-response functions show the effects of any possible sudden shocks on the variables. Impulseresponse functions have also been used to study the effects of speculative actions on wheat prices. Figure 5 shows the periodic relations of the variables. Here one period is equal to 1 month. Especially, in the first three periods, the shocks effected the prices ne gatively. Later on, the prices became more stable. So it can be said that speculative movements may form bubbles in wheat prices for a short period.

The findings show, the speculative shocks effect the wheat prices negatively in short run. The effect loses its significance after the third period. This finding also supports previous studies like McPail et al. [28]. According to Ikeda and Shibata [34], the bubbles can be random and endogen. The pices are formed based on 
Inverse Roots of AR Characteristic Polynomial

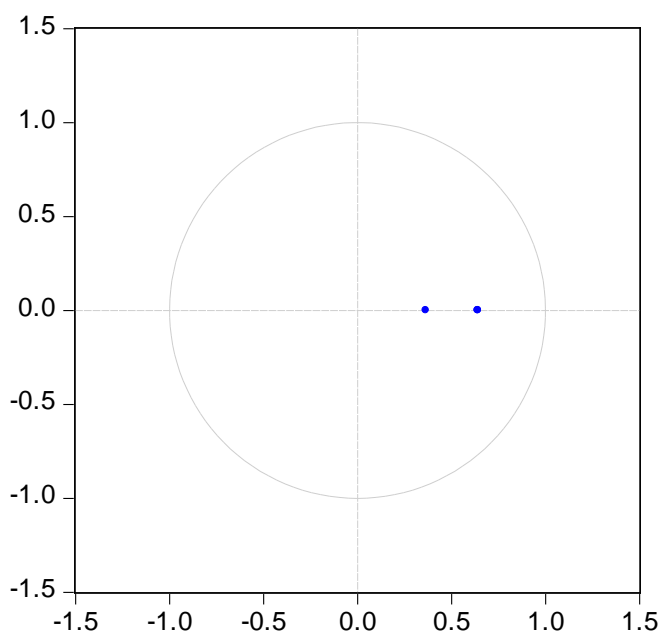

Figure 4. Inverse roots of AR characteristic polynomial.

Table 3. Determination of lag structure.

\begin{tabular}{|c|c|c|c|c|c|c|}
\hline Lag & Log Likelihood & LR & FPE & AIC & SC & HQ \\
\hline 0 & 572.6855 & NA & $4.43 e^{-06}$ & -6.651293 & -6.577803 & -6.621474 \\
\hline 1 & 630.6056 & 113.1304 & $2.36 \mathrm{e}-06^{*}$ & $-7.281937^{*}$ & $-7.134958^{*}$ & -7.222299 \\
\hline 2 & 631.3006 & 1.341331 & $2.45 \mathrm{e}^{-}-06$ & -7.243282 & -7.022815 & -7.153826 \\
\hline 3 & 632.5788 & 2.436783 & $2.53 e^{-}-06$ & -7.211448 & -6.917491 & -7.092173 \\
\hline 4 & 634.9771 & 4.516069 & $2.58 e^{-06}$ & -7.192715 & -6.825269 & -7.043621 \\
\hline 5 & 637.3384 & 4.391105 & $2.63 e^{-}-06$ & -7.173548 & -6.732613 & -6.994635 \\
\hline 6 & 637.8743 & 0.984118 & $2.74 \mathrm{e}^{-}-06$ & -7.133033 & -6.618608 & -6.924301 \\
\hline 7 & 639.1738 & 2.355808 & $2.83 e^{-}-06$ & -7.101448 & -6.513534 & -6.862898 \\
\hline 8 & 646.6148 & $13.31554^{*}$ & $2.72 \mathrm{e}^{-06}$ & -7.141694 & -6.480291 & -6.873325 \\
\hline
\end{tabular}

Table 4. Autocorrelation LM test.

\begin{tabular}{|c|c|c|}
\hline Lags & LM-Stat & Prob. \\
\hline 1 & 1.293558 & 0.8625 \\
\hline 2 & 1.662281 & 0.7976 \\
\hline 3 & 3.289384 & 0.5106 \\
\hline 4 & 2.724388 & 0.6050 \\
\hline 5 & 2.584037 & 0.6297 \\
\hline 6 & 2.143401 & 0.7094 \\
\hline 7 & 10.33203 & 0.0352 \\
\hline 8 & 5.914256 & 0.2056 \\
\hline 9 & 2.934405 & 0.5689 \\
\hline 10 & 4.197542 & 0.3799 \\
\hline 11 & 6.089844 & 0.1925 \\
\hline 12 & 0.814056 & 0.9366 \\
\hline
\end{tabular}


Accumulated Response to Cholesky One S.D. Innovations \pm 2 S.E.

Accumulated Response of LCFTCINDEX to LCFTCINDEX

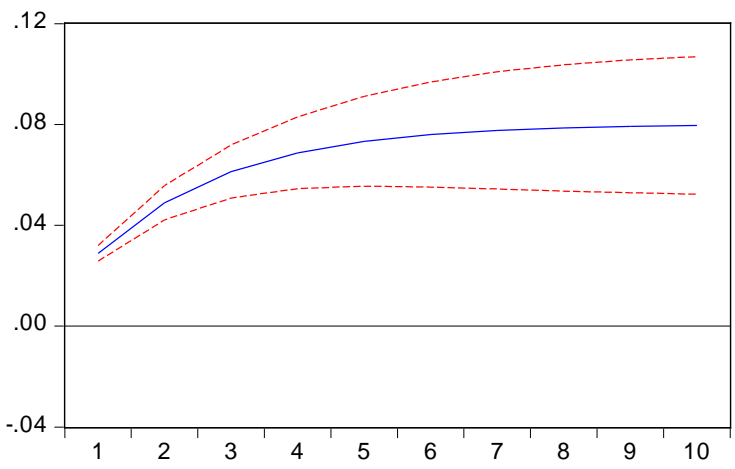

Accumulated Response of LSPOTPRICE to LCFTCINDEX

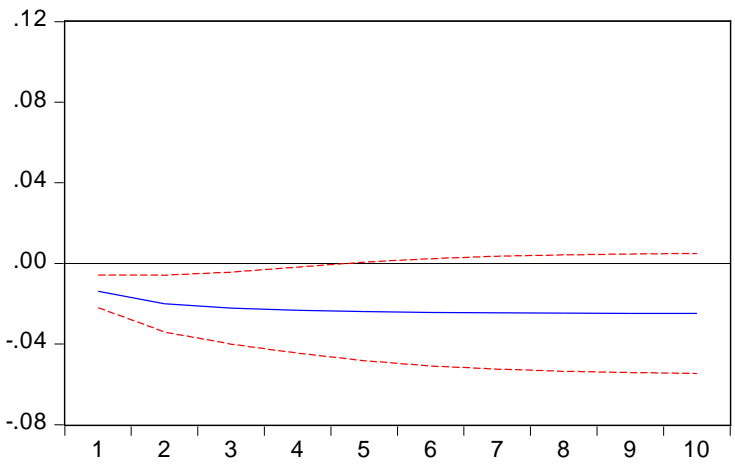

Accumulated Response of LCFTCINDEXto LSPOTPRICE

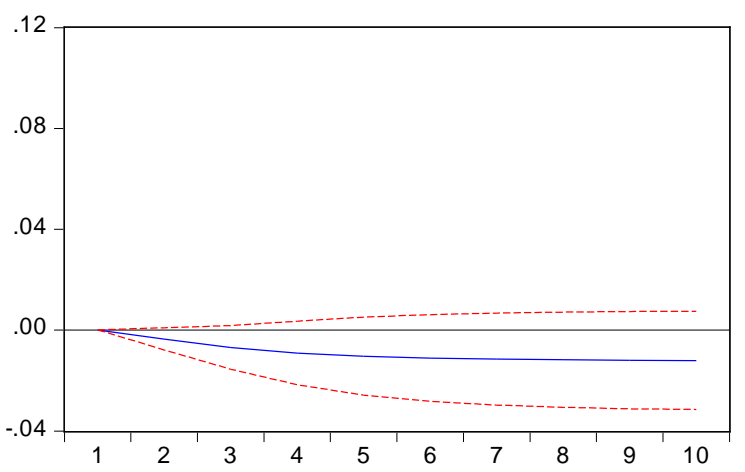

Accumulated Response of LSPOTPRICE to LSPOTPRICE

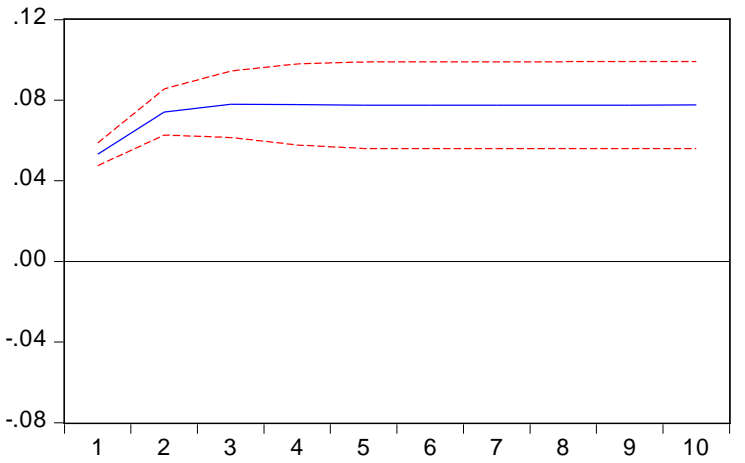

Figure 5. Impulse-response analysis of wheat prices.

the expectations of rational investors about the economy. Investors discount the future and shape the prices. Fundamental dependent bubbles are different from traditional rational bubbles. These bubbles expand contracts periodically. Moreover, they might have nigative or positive correlation with economic factors. The shocks in wheat prices do not have statistically significant effect on speculative index. It means that the speculative movements are independent of price shocks. Moreover, speculative movements are seen to evolve independently. On the otherhand, the shocks in speculative movement have significance effect on wheat prices in the first three months. In other words, speculative movements form short term bubbles on wheat prices. This might lead to permanent damage in wheat prices. However, it needs to be mentioned, this finding is not enough to conclude that this bubble formation was one of the reasons of global food crisis in 2005-2008.

Variance Decompostion is a tool used to explain how much variance in a variable can be explained by the variable itself and by other variables. The results of variance decompostion analysis are presented in Table 5 . It shows that $6.02 \%-6.12 \%$ volatility in the wheat price is explained by speculative movements. It starts losing its explanatary power after the first month. In other words, the speculative movements effect wheat prices in short run significantly; and may lead to permanent damage in the prices.

\section{Conclusions}

This study analyzes the relation between wheat price shocks and speculative movements. The findings show that the speculative movements effect wheat prices in short-run significantly. The effect can be stronger in recession or economic instability; and may lead to increasein wheat price volatility.

Speculators try to form the prices based on their expectations about future market movements. So, expectations are crucial in price formation. In order to control the speculative movements and ensure long term market equilibrium, world wheat harvest estimates can be used as an important policy tool. Moreover, in case of instability in world economy and high volatility in the stocks, the measures like export restrictions are not 
Table 5. Variance decompositon of wheat prices.

\begin{tabular}{cccc}
\hline Period & S.E. & CFTCINDEX & SPOTPRICE \\
\hline 1 & 0.054689 & 6.025315 & 93.97469 \\
2 & 0.058267 & 6.088137 & 93.91186 \\
3 & 0.058740 & 6.110908 & 93.88909 \\
4 & 0.058805 & 6.117954 & 93.88205 \\
5 & 0.058815 & 6.120025 & 93.87998 \\
6 & 0.058816 & 6.120642 & 93.87936 \\
7 & 0.058817 & 6.120835 & 93.87916 \\
8 & 0.058817 & 6.120900 & 93.87910 \\
9 & 0.058817 & 6.120923 & 93.87908 \\
10 & 0.058817 & 6.120932 & 93.87907 \\
\hline
\end{tabular}

recommended. As it may increase speculative and make market manipulation easier. Furthermore, the measures like reducing the intermediaries in the wheat market, preventing informality, tranparency in the stocks and preventive measures in the financial markets may partially reduce the speculation in comodity markets.

\section{References}

[1] Stigler, M. and Prakash, A. (2011) The Role of Low Stocks in Generating Volatility and Panic. Safeguarding Food Security in Volatile Global Markets, 327-341.

[2] Headey, D. and Fan, S. (2008) Anatomy of a Crisis: The Causes and Consequences of Surging Food Prices. Agricultural Economics, 39, 375-391. http://dx.doi.org/10.1111/j.1574-0862.2008.00345.x

[3] Mitchell, D. (2008) A Note on Rising Food Prices. Policy Research Working Paper. The World Bank.

[4] Serra, T. and Gil, J.M. (2013) Price Volatility in Food Markets: Can Stock Building mitigate Price fluctuations? European Review of Agricultural Economics, 40, 507-528. http://dx.doi.org/10.1093/erae/jbs041

[5] Roache, S.K. (2010) What Explains the Rise in Food Price Volatility? International Monetary Fund (IMF) Working Papers 10/129. International Monetary Fund, Washington DC.

[6] Shively, G.E. (1996) Food Price Variability and Economic Reform: An ARCH Approach for Ghana. American Journal of Agricultural Economics, 78, 126-136. http://dx.doi.org/10.2307/1243784

[7] Hanjra, M.A. and Qureshi, M.E. (2010) Global Water Crisis and Future Food Security in an Era of Climate Change. Food Policy, 35, 365-377. http://dx.doi.org/10.1016/j.foodpol.2010.05.006

[8] Till, H. (2011) A Review of the G-20 Meeting on Agriculture: Addressing Price Volatility in the Food Markets. EDHEC-Risk Institute, Principal Premia Capital Management, LLC. www.edhec-risk.com

[9] Baffes, J. and Haniotis, T. (2010) Placing the 2006/08 Commodity Price Boom into Perspective. Working Paper 5371, Policy Research, The World Bank (WB) Development Prospects Group, Washington DC.

[10] Du, X., Yu, C.L. and Hayes, D.J. (2011) Speculation and Volatility Spillover in the Crude Oil and Agricultural Commodity Markets: A Bayesian Analysis. Energy Economics, 33, 497-503.

[11] Piesse, J. and Thirtle, C. (2009) Three Bubbles and a Panic: An Explanatory Review of Recent Food Commodity Price Events. Food Policy, 34, 119-129.

[12] Ott, H. (2014) Extent and Possible Causes of Intrayear Agricultural Commodity Price Volatility. Agricultural Economics, 45, 225-252.

[13] Gilbert, C.L. (2010) How to Understand High Food Prices. Journal of Agricultural Economics, 61, 398-425. http://dx.doi.org/10.1111/j.1477-9552.2010.00248.x

[14] Irwin, S.H., Sanders, D.R. and Merlin, R.P. (2009) Devil or Angel? The Role of Speculation in the Recent Commodity Boom (And Bust). Journal of Agricultural Applied Economics, 41, 393-402.

[15] Gutierrez, L. (2012) Speculative Bubbles in Agricultural, Commodity Markets. European Review of Agricultural Economics, 28, 1-22. 
[16] Espostia, R. and Listorti, G. (2013) Agricultural Price Transmission across Space and Commodities during Price Bubbles. Agricultural Economics, 44, 125-139.

[17] Wright, B. (2011) The Economics of Grain Price Volatility. Applied Economics Perspective Policy, 33, 32-58.

[18] Nazlığlu, S., Erdem, C. and Soytaş, U. (2013) Volatility Spillover between Oil and Agricultural Commodity Markets. Energy Economics, 36, 658-665.

[19] Sanders, D. and Irwin, S. (2010) A Speculative Bubble in Commodity Futures Prices? Cross-Sectional Evidence. Agricultural Economics, 41, 25-38.

[20] Serra, T., Zilberman, D. and Gil, J.M. (2011) Price Volatility in Ethanol Markets. European Review of Agricultural Economics, 38, 259-280.

[21] Kim, K. and Chavas, J.P. (2002) A Dynamic Analysis of the Effects of a Price Support Program on Price Dynamics and Price Volatility. Journal of Agricultural and Resource Economics, 27, 495-514.

[22] Dawe, D. (2009) The Unimportance of Low World Grain Stocks for Recent World Price Increases. Agricultural Economics Division (ESA) Working Paper No. 09-91, FAO, Rome.

[23] Balcombe, K. (2011) The Nature and Determinants of Volatility in Agricultural Prices: An Empirical Study. In: Prakash, A., Ed., Safeguarding Food Security in Volatile Global Markets, FAO, Rome, 85-106.

[24] Frankel, J.A. (2006) The Effect of Monetary Policy on Real Commodity Prices. Working Paper 12713, NBER.

[25] Headey, D. and Fan, S. (2011) Rethinking the Global Food Crisis: The Role of Trade Shocks. Food Policy, 36, 136146. http://dx.doi.org/10.1016/j.foodpol.2010.10.003

[26] Calvo, G. (2008) Exploding Commodity Prices, Lax Monetary Policy, and Sovereign Wealth Funds. http://www.voxeu.org/article/exploding-commodity-prices-signal-future-inflation

[27] Rosegrant, M.W., Zhu, T., Msangi, S. and Sulser, T. (2008) Global Scenarios for Biofuels: Impacts and Implications. Review of Agricultural Economics, 30, 495-505. http://dx.doi.org/10.1111/j.1467-9353.2008.00424.X

[28] McPhail, L.L., Du, X. and Muhammad, A. (2012) Disentangling Corn Price Volatility: The Role of Global Demand, Speculation, and Energy. Journal of Agricultural and Applied Economics, 44, 401-410.

[29] Commodity Futures Trading Commission (2013) http://www.cftc.gov/OCE/WEB/data.htm

[30] United States Department of Agriculture Economic Research Service (2013) http://www.ers.usda.gov/data-products/wheat-data.aspx\#.UqVz0fTwaHQ

[31] Alptekin, V. (2009) Türkiye’de Dış Ticaret—Reel Döviz Kuru İlişkisi: Vektör Otoregresyon (Var) Analizi Yardımıyla Sınanmasi. Niğde Üniversitesi İ̈BF Dergisi, 2, 132-149.

[32] Çınar, G., Hushmat, A. and Isın, F. (2015) Relationship between Exports of Processed Agricultural Products and Real Exchange Rate Shocks: The Case of Turkey. Ege Üniversitesi Ziraat Fakültesi Dergisi, 52, 85-92.

[33] Kadılar, C. (2000) Uygulamalı Çok Değişkenli Zaman Serileri Analizi. Bizim Büro Basımevi, Ankara, 186.

[34] Ikeda, S. and Shibata, A. (1992) Fundamentals-Dependent Bubbles in Stock Prices. Journal of Monetary Economics, 30, 143-168. 